\title{
Religious Print in Settler Australia and Oceania
}

\author{
Timothy Stanley $\mathbb{D}$
}

check for

updates

Citation: Stanley, Timothy. 2021. Religious Print in Settler Australia and Oceania. Religions 12: 1048. https://doi.org/10.3390/rel12121048

Academic Editors: Kevin Schilbrack and Christopher Metress

Received: 16 October 2021

Accepted: 23 November 2021

Published: 25 November 2021

Publisher's Note: MDPI stays neutral with regard to jurisdictional claims in published maps and institutional affiliations.

Copyright: (C) 2021 by the author. Licensee MDPI, Basel, Switzerland. This article is an open access article distributed under the terms and conditions of the Creative Commons Attribution (CC BY) license (https:// creativecommons.org/licenses/by/ $4.0 /)$.
School of Humanities, Creative Industries and Social Sciences, College of Human and Social Futures, The University of Newcastle, Callaghan 2308, Australia; timothy.stanley@newcastle.edu.au

\begin{abstract}
A distinctive feature of the study of religion in Australia and Oceania concerns the influence of European culture. While often associated with private interiority, the European concept of religion was deeply reliant upon the materiality of printed publication practices. Prominent historians of religion have called for a more detailed evaluation of the impact of religious book forms, but little research has explored this aspect of the Australian case. Settler publications include their early Bible importation, pocket English language hymns and psalters, and Indigenous language Bible translations. As elsewhere in Europe, Australian settlers relied on print to publicize their understanding of religion in their new context. Recovering this legacy not only enriches the cultural history of Australian settler religion, it can also foster new avenues through which to appreciate Australia's multireligious and Indigenous heritage.
\end{abstract}

Keywords: book history; Pietism; indigenous translation; colonialism; print

In an essay on "Religion and Bible", Jonathan Z. Smith proposed that scholars of religion "reinsert biblical and other canonical scriptures into the general history of the study of religion" (Smith 2009, p. 10). ${ }^{1}$ In that same essay, he cited Robert Darnton's cultural history of the book as a direction to pursue (Smith 2009, p. 5, citing; Darnton 1999, p. 3). As Smith understood, studying religion in this way could uncover unexplored insights into the technical capacity to make religious texts in printed form (Smith [1992] 2013, p. 33; Cf. Smith 1971, p. 136). While Smith was primarily concerned with the broader relation between biblical and religious studies, he called for new materialist studies of the book in this context. However, this call has thus far resulted in little more than maps to new textual territories yet to be explored (Smith [1999] 2004, p. 209; Cf. Smith 1978).

In response, the following essay is addressed to historical aspects of early Australian settler religious print. It aims to provide unique insights into Australia's religious past with reference to material aspects of its publication practices. Such cultural history can foster a unique capacity to better understand Australian settler religion and recover glimpses into the Indigenous languages they encountered in translation. The first section below outlines the importance of publication practices in the European culture appropriated by settler Australians. This includes the impact of Pietist reading practices upon changes to the public understanding of religion in that context. Section two goes on to focus on the early Australian settler importation of English language religious texts. Thirdly, some of the first English language sacred texts printed in Australia will be evaluated. Fourthly, the earliest religious scriptures printed in Australia were translations into Indigenous languages of Oceania. Those translations have been tabulated as a map of the scope of that encounter. In sum, evaluating settler religious print in this way illuminates how their interior, private notion of religion relied upon a rich material culture.

\section{Australia's Printed Public}

Several narrations of the history of Australian religion note its distinctive appropriation of European culture. For instance, as Monsma and Soper summarized in their comparison between five different church-state arrangements across the world, Australia differs from the United States and France in its "pragmatic pluralism" (Monsma and Soper 
2009, p. 93). From the 1836 New South Wales Church Act, through the debates around Section 116 of the Australian Constitution written at the time of Federation in 1901, Australian political institutions balanced a variety of highly contentious religious interests (Monsma and Soper 2009, pp. 97, 101). This sentiment is echoed in John Gascoigne's The Enlightenment Origins of European Australia. As he puts it at one point, "the early colony, then, had a mixed ideological parentage" (Gascoigne 2002, p. 20). This included both the English colonial practices that "regarded religion as good for social order", but also the seeds of critique amidst diverse religious traditions with differing views as well as varying degrees of dissent (Gascoigne 2002, p. 20). More recent commentary has only reiterated this plurality endemic to Australian history (Barker 2015). ${ }^{2}$ The difficulty is that Australia resists any simple progress towards the European ideal of private religious forms of life (Chavura and Tregenza 2015, p. 26). Insisting "that religion is a thoroughly private affair" will likely result in misreading the Australian past (Chavura and Tregenza 2015, p. 26).

However, critics of Australia's European heritage have thus far tended to discuss the public-private distinction in terms of political institutional arrangements. For instance, those noted above have critiqued the relevance of the ideal of private religion with reference to its establishment by an institutional state or in terms of government support. ${ }^{3}$ In response, the following essay focuses on the production of the public itself in material practices of print. To this end, it is worth summarizing briefly Jürgen Habermas's influential account of The Structural Transformation of the Public Sphere. He explains how the exchange of newspapers, journals, and books coalesced with a new form of public recognition in deliberative society (Habermas [1962] 1989, p. 65). Two aspects of his narration require qualifications here.

Firstly, commentators were quick to note the paradoxical relation between the public and private that occurs in Habermas's account of the rise of the public sphere (Baker 1996, p. 186). As Roger Chartier also noted, Habermas's public is not identified with the state (Chartier 2003a, p. 17). Instead, it is literally produced through the publications of private citizens (Baker 1996, p. 185). As Habermas puts it, "the bourgeois public sphere evolved in the tension-charged field between state and society. But it did so in such a way that it remained itself a part of the private realm" (Habermas [1962] 1989, p. 140; Cf. Baker 1996, p. 187). Habermas admits that key cultural conditions to make this sphere of public readers and writers possible were new in locations such as eighteenth-century Britain and France. Moreover, he acknowledges both that this public sphere did not always exist in perfected form (Habermas [1962] 1989, pp. 89-95), ${ }^{4}$ as well as that it was itself inadequate in its enfranchisement of a limited bourgeois class (Habermas [1962] 1989, pp. 130-32). Nonetheless, it is important to pay attention to why various aspects of the public he describes did occur, as has been studied by historians of United States context (Warner 1992). To this end, further investigations of Australian settler publication practices are particularly apropos.

Secondly, Habermas's account of religion in this sphere emphasizes its privatization in the Reformation era of the sixteenth and seventeenth centuries. Here, he briefly discusses the handover of sovereignty between the ecclesial and political realms (Habermas [1962] 1989, pp. 11-12). However, this delineation was less clear historically than Habermas portrays. For instance, others such as William Cavanaugh's The Myth of Religious Violence have challenged neat delineations between religion and political reason in sixteenth to eighteenth-century Europe (Cavanaugh 2009, pp. 141-42). Critics have also since explored public reason's antecedent grounding in the religious communities of the era (Zaret 1996, pp. 213-14). However, what has garnered less attention is how religious publication practices themselves contributed to the cultural conditions necessary to produce wide public acceptance of a private notion of religion. As well, Habermas underplays the significance of the way the public understanding of religion changed during this time. Religion may no longer have dominated the public sphere, but it certainly persisted in printed form. 
In brief, Habermas argues that the public sphere that arose in the seventeenth to eighteenth-centuries: (1) relied on private capacities to print or publicize; (2) idealized itself as a project to achieve; and, (3) remained distinct from a private notion of religion. In each case, the historical accounts of the rise of print culture can provide meaningful responses that distinctly adjust our picture of how religion changed through engagement with print practices. Over the last thirty years, book history has blossomed into a diverse and interdisciplinary research area (Lyons and Marquilhas 2017; Finkelstein and McCleery 2005; Adams and Barker 2001; Darnton 1990). Recent work now regularly investigates the book's wider social and political contexts (Eliot and Rose 2007; Vliet 2007; Howsam 2014). Moreover, religious aspects of the book's history have increasingly been called for by progenitors in the field (Eisenstein 2005, pp. 335-36).

The intersection between print and religious reform in Europe is of particular relevance as precursors to the Australian settler example. While print did not result in an immediate change to the religious book nor reading practices of Europe, ${ }^{5}$ this is not to say that by the seventeenth and eighteenth-centuries, new forms of Christianity did eventually start to coincide with increased literacy and book ownership rates. Christian piety of this era was not to be understood strictly in terms of individual reading practices. ${ }^{6}$ Nonetheless, the rise of Pietist traditions did interact with and relied upon new forms of religious print (Shantz 2013, p. 204). ${ }^{7}$

Roger Chartier, in particular, has provided bibliographic context of the relationship between Pietism and print. Firstly, he notes the specific religious initiatives that affected reading rates in Europe, such as laws promoting reading that did not necessarily result in writing skills (Chartier 2003b, pp. 118-19). The religious reformations of the sixteenthcentury did not produce increased literacy. Instead, "it was not until the so-called Second Reformation initiated by Pietism at the end of the seventeenth century that all the faithful were expected to learn what was in the Bible" (Chartier 2003b, p. 119; Cf. Green 2000, p. 97). In that decade, the Bible started to become sold at lower prices for wider readership (Chartier 2003b, p. 120). Secondly, Chartier shows how new Pietist religious groups influenced increased book ownership as well. This is tracked through inventories compiled as records of possessions after a person's death. While these do not indicate readership, per se, they nonetheless show similar increases in book ownership amongst Protestant cultures by the mid-eighteenth-century. "In the German Lutheran cities of Tübingen, Spire and Frankfurt, books are mentioned in respectively 89,88 , and 77 percent of all inventories" (Chartier 2003b, p. 130). This compares to 22 percent of inventories in French Catholic Paris. Personal libraries were organized around key texts, chiefly the Bible. Despite variances, reading practices had a profound effect on the development of notions of private life. Personal engagement with texts allowed individuals to cultivate an inner life apart from previous mediators (Chartier 2003b, p. 116).

Chartier's work reiterates this seventeenth and eighteenth-century theme, where Pietists evidenced significant increases in both readership and book ownership. The form of reading also intensified its privacy in this community, where religious life was encountered through printed texts. The Bible, in particular, is cited as a text that people returned to again and again. In sum, Pietist religious groups arose alongside formal changes to how religious publications were produced and owned by individuals. Unwittingly or otherwise, these groups contributed to religion's identification with interior styles of reading. This context of religious reading and book ownership should inform how to reframe private religion in the rise of the public sphere in the seventeenth to eighteenth-centuries. If we take that Pietist contribution to religious print as a starting place, then the Australian case looks to be a continuation of practices in Europe. By the time of the Australian settlers, these forms of Christianity had impacted the Anglicanism of the Australian settlers, such as John Wesley's Methodism. ${ }^{8}$ 


\section{Settler Australian Religious Print Importation}

By the nineteenth-century, printing practices were embedded in Australian settler religious traditions. ${ }^{9}$ The first example concerns the colonial importation of Bibles to Australia. It is important to note that Australian settlers from the first voyages onwards brought one of their key religious artifacts in the form of the Bible. Meredith Lake's recent, The Bible in Australia: A Cultural History provides much-needed context in this regard. For instance, she analyses Captain James Cook's Bible, which he brought with him on his first 1770 exploration of Australia. This Bible is located in the State Library of New South Wales, and its form, images, and inclusions concern specific aspects of Cook's eighteenth-century Anglican heritage (Lake 2018, p. 21). Moreover, this Bible was as much an artifact of European print technology as it was an example of the early explorer's religious views depicted within its pages.

The printed Bible was also a visible part of settler culture and society soon after settlement. The first official chaplain to New South Wales, Richard Johnson, arrived in 1789 and with him "100 full Bibles, 400 New Testaments, 500 Psalters, and 200 copies of the Sermon on the Mount" (Lake 2018, p. 28). This importation of religious texts only increased over time. As histories of the British and Foreign Bible Society attest concerning Australia, from 1835-1854, it is estimated that some 24,141 Bibles and testaments had been distributed in the Australian colonies (Canton 1904, p. 417). Such efforts went far and wide to ensure that these Bibles could make their way into the farthest reaches of Australia, aiming to turn isolation into religious solitude.

Such Bible importation has to be set in the context of the wider population by 1851 of around 405,000 settlers (Carey 2011, p. 19). As well, the Bible was not alone in this context as other forms of reading novels and newspapers were developing akin to Habermas's account of an expanding public sphere of letters (Kirsop 1969, 1988). We should also not overestimate the limited effects such books may have had on the populace's specific beliefs. The same chaplain who brought 100 Bibles with him wrote somewhat disparagingly of his efforts in his diary two years later. "Have been now nearly two years preaching, as well as privately admonishing these people; but after all, they seem to grow more and more abandoned ... One sold his Bible for a glass of liquor; others tear them up for waste paper" (Gascoigne 2002, p. 23; citing Macintosh 1978, p. 107). Reports from the first Auxiliary Bible Society of New South Wales established in 1817 were similarly stark at times. Their sixth report in 1822 noted that "there are few applicants for the Bible" (Gascoigne 2002, p. 23; citing Auxiliary Bible Society of New South Wales 1822-1823, p. 8).

However, it is possible to comment upon how this Australian importation of Bibles reflected a wider context of European culture of the eighteenth and nineteenth-centuries. Johnson, in particular, is a relevant example because he had adopted key aspects of the European Pietist movement that had taken root in English Christianity (Lake 2018, p. 27). As historians of missionary practice have noted, such traditions were masters of "imperial print culture" (Carey 2010, p. 448; Cf. Johnston 2001, 2003). In both its Methodist and Anglican forms, missionaries played a crucial role in the proliferation of printed religious publications over the course of the nineteenth-century (Prentis 2015, p. 36). This may seem like an insignificant part of Australia's overall history. However, it provides an example of how Australian settler religion relied upon a material information culture.

\section{Settler English Language Religious Print}

Looking at the religious printing practices developed by Australian settlers themselves, there are no known examples of whole Bibles printed in Australia in the eighteenth and nineteenth-centuries. ${ }^{10}$ However, this is not to say that print did not foster the capacity for distinctive aspects of religious printing to flourish. It is all the more striking then when we note the earliest Christian scriptures Australian settlers did print.

For instance, the first printed English language collection of Christian scriptures were of a Psalm and hymn book in 1828. It is held in the State Library of New South Wales and includes eighty-eight pages in leather binding. John Ferguson's Bibliography of Australia cites 
this text as a hymn book with Psalms. However, its title was the "Select Portions of Brady and Tate's Version of the Psalms" (Tate and Brady 1828). This was an English language translation of portions of all 150 Psalms that made efforts to rhyme the verses. As already noted, it was not uncommon for Australian settlers to import abridged compilations of Christian scriptures. As noted in the next section below, Indigenous language translations were also printed in abridged form. Hence, this 1828 collection of Psalms should be cited as the first English language Christian scriptures printed in Australia.

When one considers the first hymn-book, Ferguson's Bibliography of Australia takes care to note an 1821 edition printed by George Howe in Sydney (Wesley 1821). While Ferguson cites this as the "first hymn-book of the Church of England printed in Australia" (Ferguson 1941, p. 501), the collection of hymns clearly inflected Pietist interests. This hymn-book is also held in the State Library of New South Wales and is a compact 130 pages. It begins with the advertisement, "it has been long a subject of regret, that the great scarcity of Hymn-Books in this Colony, particularly in the interior Towns and Districts, has given rise to many serious inconveniences among the Worshippers of God in the Wesleyan Congregations" (Howe 1821a). In typical Wesleyan form, the hymns themselves go on to allude to scriptural themes and Christian theology of their Pietist variety. Despite this early Methodist printed hymnal, Ferguson also notes that similar hymn-books were printed for Roman Catholic worshipers by the end of that decade as well in 1828 (Ferguson 1941, p. 501). Hence, around this period, English language collections of hymns were produced for both Protestant and Catholic worship.

These early English language religious texts have drawn scholarly attention to two of Australia's earliest printers, George Howe (1771-1821) and his son Robert (1795-1829). George was the first professionally trained printer in Australia, having been apprenticed in the trade by his father Thomas Howe on the Caribbean island of St. Kitts (Robb 2003, p. 3). By rather difficult circumstances, George arrived with Robert in Sydney in 1800, on The Royal Admiral convict transportation ship. ${ }^{11}$ George's wife Mary was pregnant at the time and passed away of typhoid during the trip (Robb 2003, p. 22). The missionary on the ship Mr. Youll left notes on the event and presided over her burial at sea (Robb 2003, p. 25). After this tragedy, Robert was then "left to the care of Wesleyan missionaries bound for Tahiti by the same ship" (Blair 1985, p. 5). As Blair notes, this encounter may have affected George's own faith, "as he was later a chapel member, as was his son, Robert" (Blair 1985, p. 6). Upon arrival, George was soon appointed government printer, a role that relied on his expertise with the wooden screw press imported to Sydney in 1788 (Borchardt 1988, p. 2). He went on to become an influential founder of the Sydney Gazette, which began on 5 March 1803 (Borchardt 1988, p. 5). Within months he was granted a conditional pardon (Blair 1985, p. 11).

Concerns have been raised about George and Robert's place in the sphere of the government authorities in Sydney at this time (Blair 1985, p. 2). It is fair to say that George's influence upon early print was varied for an 1803 population estimated at "probably no more than 30 percent literacy and a population of about 7000" (Borchardt 1988, pp. 5-6). However, as the population grew and diversified, so too did Howe's capacity to publish a wider range of viewpoints for more diverse audiences. Moreover, this diversity coincided with Howe's reliance upon advertising from Sydney's growing business community rather than sole government patronage (Blair 1985, p. 12). While commentators often cite George's interest in poetry and natural history (Blair 1985, pp. 15-16), his publication of religious texts is no less significant for the local community of growing readership. Beyond printing the early 1821 hymnal noted above, he was also one of the founding members recorded of the British and Foreign Bible Society of New South Wales's Sydney Auxiliary in 1817 (Wright and Clancy 1993, p. 6). ${ }^{12}$ 
Upon George's death in 1821, Robert took over responsibilities for the print business. While both were a part of early religious printing activities, Robert was more active in early Methodist Pietism in Australia. From 1821-1822 he published the first Australian Magazine, which maintained the ecumenical tagline: "Compendium of religious, literary, and miscellaneous intelligence". This publication was approved by Governor Lachlan Macquarie at the time (Wright and Clancy 1993, p. 12), with caveats to avoid sectarian interests. The magazine explicitly set its agenda accordingly in some of its prefatory remarks in the December index to the first volume. "While it is our determination to give to the Australian Magazine a decidedly religious character, it is far from our intention or wish to make it the organ of sectarian peculiarities" (Howe 1821b, p. iv). The magazine was also promoted with the support of the Sydney Methodist missionaries for a time (Wright and Clancy 1993, p. 12). However, the Methodist leadership eventually advised Robert to abandon the project, which he agreed to do in 1822.

These examples demonstrate the influential relationships between religious worshippers and the sympathies of Sydney's earliest printers. Nonetheless, as with Bible importation, these early forays into printed religious texts were not necessarily representative of the population at large. It is estimated that by 1854, the Methodists "had possessed only two chapels and a few other preaching places in Sydney and on the Hunter River and their minuscule membership of 116 was served by two ministers" (Wright and Clancy 1993, p. 52).${ }^{13}$ Even so, this small community's printing practices had an outsized influence upon the visibility of religion in early Australian settler life. As one commentator summed up Howe's ethos: "His world view was that of a small colonial capitalist, seeking a stable, ordered and prosperous community, where British loyalties and Christian morality would prevail and individual enterprise thrive" (Blair 1985, p. 17). Print was a critical technical mechanism to promote this view. Religion's visibility in this sense was not limited to attendance and membership measurements but endemic to the rise of print in an Australian public sphere. ${ }^{14}$

With each of these cases of early settler printed Christian scriptures and hymn-books, it is notable that they were fragmentary compilations of religious texts. They did not produce Bibles in a fixed list of complete canonical units. Howe's Psalms were a particular abbreviated form of poetry that explicitly aimed to rhyme the English language. It also reflected early settler interests in congregational hymns for singing. The Wesleyan hymns were themselves redactions of scriptural themes reworked for congregational engagement in the text.

\section{Settler Indigenous Language Religious Print}

Religious print was not limited to the English language for early Australian settlers. It also included the printing of Indigenous language scriptures primarily for peoples of Oceania. Again, it is important to note that the Pietist influences of this era aimed to provide Indigenous peoples with the same reading practices as their European settlers. That is, a vernacular experience of the religious text. ${ }^{15}$

When it comes to the New Testament and other parts of the Christian Bible, two of the earliest printed editions stand out. The first is of Scriptural extracts in the Tahitian language printed by George Howe in Sydney in 1814. An example is located in the State Library of New South Wales as Parau no Iesu Christ te Temaidi no te Atua: E no te mou pipi nona (1814). Ferguson's Bibliography of Australia again provides special notes on this text, which he refers to as an "epitome of the Gospels and Acts in Tahitian" (Ferguson 1941, p. 242). It was evidently erroneously described in its sale in London as the "first book printed in Australia" (Ferguson 1941, p. 242). However, it is the first book of Christian scriptures printed in Australia in any language. These particular publications, however erroneously attributed, were noted in London, as well as in the Sydney Gazette's 3 December 1814 issue (Ferguson 1941, p. 242). ${ }^{16}$ That the first religious texts were printed in Indigenous languages echoed the practice of the North American context. ${ }^{17}$ 
Secondly, a more widely known translation of the Maori language was also printed in Sydney in $1827 .{ }^{18}$ This was one of the earliest Maori language printed texts. ${ }^{19}$ According to Ferguson, it includes the "first three chapters of Genesis ... the first chapter of St. John ... seventeen verses of Exodus ... thirty verses of St. Mathew ... The Lord's Prayer ... and hymns" (Ferguson 1941, pp. 416-17). The translation was the work of Mr. T. Shepherd, and it was put through the press by Mr. R. Davis (Ferguson 1941, p. 417). Four hundred copies of this text were printed as the first translation into the Maori language at the cost of forty-one pounds sterling. ${ }^{20}$ Funding was provided by the New South Wales Auxiliary of the British and Foreign Bible Society. It is also preserved in the State Library of New South Wales as Kenehihi: Ko te tahi o nga upoko (1827).

Australian settlers were not alone in their vernacular interests in Indigenous language Bible printing. Bible societies record a wide range of translations, as well as the printing of primers and dictionaries. These linguistic works now preserve vital insights into the past languages of Indigenous peoples. This was particularly true of the case of Lancelot Threlkeld's translation work regarding the Hunter River Lake Macquarie language of the Awabakal people (Threlkeld 1827, Threlkeld [1834] 1892). His translation of the Gospel of Luke was first published in 1891 and again in 1897 (Threlkeld 1897). The preface to that work was dated 15 August 1857, but its publication was well after his missionary practices had ended. As recent scholars have argued, if its missionary impact was marginal, Thelkeld's work nonetheless provides vital insight into Awabakal language and culture today (Carey 2010; Cf. Johnston 2006). It now best features in contemporary scholarship as a window into the linguistic past. ${ }^{21}$

Again, as in the English religious texts, Australia's early printed Indigenous language Christian scriptures were fragmentary collections sometimes accompanied by hymns and catechisms. ${ }^{22}$ They were part of an editing process by missionaries with limited resources to translate and produce such materials. There is not sufficient space here to summarize the complex history of interactions between missionaries and diverse Indigenous peoples during this era (Cf. Carey 2011). However, printed Indigenous language texts did have the effect of publicizing their visibility in Australia's fledgling public sphere. Such publications are part of Australia's unique contribution to religious print that was preserved in the British and Foreign Bible Society's historical catalogues. ${ }^{23}$

That multivolume work records the overall international efforts of the nineteenthcentury and made visible unique features of its regional languages and cultures, summarized in Figure 1 below. In sum, the table below indicates 94 translations were printed between the years 1833 [1827] and 1909 in Adelaide, Brisbane, Hobart, Melbourne, and Sydney. Forty-one different languages are represented from fifteen geographical locations. The highest concentration of published translations were the forty-one printed editions from fourteen different languages of the New Hebrides [Vanuatu]. Moreover, Indigenous Australian languages included the 1864 Adelaide printing of the Narrinyeri language of South Australia (1903-1911, \#6966), and the 1891 Sydney printing of the Awabakal language of New South Wales (1903-1911, \#1907). 


\begin{tabular}{|c|c|c|c|}
\hline \multicolumn{4}{|c|}{ yum } \\
\hline Location & City & Year & \\
\hline New Hebrides & Sydney & 185 & $\# 15$ \\
\hline \multicolumn{4}{|c|}{ 2. Aniwa } \\
\hline Location & City & Year & $\#$ \\
\hline New Hebrides & Melbourne & 1877 & $\# 1625$ \\
\hline New Hebrides & Melbourne & 1877 & \#1626 \\
\hline New Hebrides & Melbourne & 1880 & $\# 1627$ \\
\hline New Hebrides & Melbourne & 1882 & \#1628 \\
\hline New Hebrides & Melbourne & 1898 & $\# 1629$ \\
\hline New Hebrides & Melbourne & 1904 & $\# 1629 a$ \\
\hline New Hebrides & Melbourne & 1904 & $\# 1629 \mathrm{~b}$ \\
\hline \multicolumn{4}{|c|}{ 3. Awabakal } \\
\hline Location & City & Year & \\
\hline New South Wales & Sydney & 1891 & \#1907 \\
\hline \multicolumn{4}{|c|}{ 4. Daui } \\
\hline Location & City & Year & \\
\hline New Guinea, Suau, South Cape & Sydney & 1885 & \#3243 \\
\hline New Guinea, Suau, South Cape & Sydney & 1892 & \#3244 \\
\hline \begin{tabular}{|l} 
New Guinea, Suau, South Cape \\
\end{tabular} & Sydney & 1895 & \#3245 \\
\hline \multicolumn{4}{|c|}{ 5. Dobu } \\
\hline Location & City & Year & \# \\
\hline British New Guinea & Sydney & 1894 & $\# 3252$ \\
\hline British New Guinea & Sydney & 1898 & \#3253 \\
\hline British New Guinea & Sydney & 1904 & \#3254 \\
\hline
\end{tabular}

\begin{tabular}{|l|l|l|l|}
\hline \multicolumn{4}{|c|}{ 6. Duke of York Island } \\
\hline & \multicolumn{1}{c|}{ City } & \multicolumn{1}{c|}{ Year } & $\#$ \\
\hline Location & Brisbane & 1882 & $\# 3267$ \\
\hline New Britain Group & Sydney & 1882 & $\# 3267$ \\
\hline New Britain Group & Sydney & 1886 & $\# 3268$ \\
\hline New Britain Group & Sydney & 1896 & $\# 3270$ \\
\hline New Britain Group & \multicolumn{2}{|c|}{} \\
\hline
\end{tabular}

\begin{tabular}{|c|c|c|c|}
\hline \multicolumn{4}{|c|}{ 7. Epi Baki } \\
\hline Location & City & Year & $\#$ \\
\hline New Hebrides & Sydney & 1886 & $\# 3480$ \\
\hline New Hebrides & Hobart & 1898 & $\# 3483$ \\
\hline
\end{tabular}

\begin{tabular}{|c|c|c|c|}
\hline \multicolumn{4}{|c|}{ 8. Eromanga } \\
\hline Location & City & Year & H \\
\hline New Hebrides & Sydney & 1868 & |\#3487 \\
\hline New Hebrides & Sydney & 1880 & $\# 3489$ \\
\hline New Hebrides & Sydney & 1890 & \#3491 \\
\hline
\end{tabular}

\begin{tabular}{|c|c|c|c|}
\hline \multicolumn{4}{|c|}{ 9. Fate } \\
\hline Location & City & Year & \# \\
\hline New Hebrides & Melbourne & 1883 & $\# 3619$ \\
\hline New Hebrides & Melbourne & 1883 & $\# 3620$ \\
\hline New Hebrides & Melbourne & 1889 & $\# 3622$ \\
\hline \begin{tabular}{|l} 
New Hebrides \\
\end{tabular} & Sydney & 1866 & $\# 3614$ \\
\hline New Hebrides & Sydney & 1874 & \#3616 \\
\hline New Hebrides & Sydney & 1877 & $\# 3617$ \\
\hline New Hebrides & Sydney & 1880 & $\# 3618$ \\
\hline New Hebrides & Sydney & 1885 & $\# 3621$ \\
\hline
\end{tabular}

\begin{tabular}{|c|c|c|c|}
\hline \multicolumn{4}{|c|}{ 10. Futuna } \\
\hline Location & City & Year & \# \\
\hline New Hebrides & Sydney & 1869 & $\# 4071$ \\
\hline New Hebrides & Sydney & |1875 & $\# 4072$ \\
\hline New Hebrides & Sydney & 1880 & $\# 4074$ \\
\hline New Hebrides & Sydney & 1888 & $\# 4075$ \\
\hline w Hebrides & Sydney & 1891 & $\# 4076$ \\
\hline
\end{tabular}

\begin{tabular}{|l|l|l|l|}
\hline \multicolumn{4}{|c|}{ 11. Keapara } \\
\multicolumn{3}{|c|}{ City } & \multicolumn{1}{c|}{ Year \# } \\
\hline Location & Sydney & 1892 & $\# 5945$ \\
\hline New Guinea & Sydney & 1895 & $\# 5946$ \\
\hline New Guinea & \multicolumn{3}{|c|}{} \\
\hline
\end{tabular}

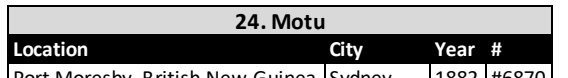

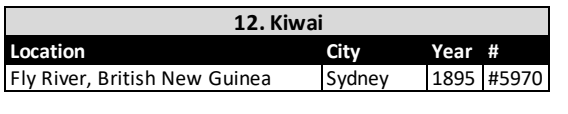
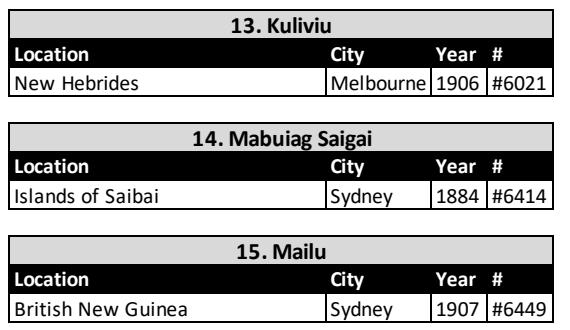
Sydney

\begin{tabular}{|l|l|l|l|}
\hline \multicolumn{3}{|l|}{ 16. Malekula-Aulua } \\
\hline Location & City & Year $\#$ \\
\hline New Hebrides & Melbourne & 1894 & $\# 6599$ \\
\hline New Hebrides & Melbourne & 1897 & $\# 6600$ \\
\hline
\end{tabular}
\begin{tabular}{|l|l|l|}
\hline New Hebrides & Melbourne $1897 \quad \# 6600$ \\
\hline
\end{tabular}
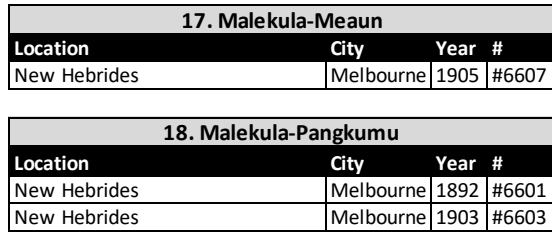

\begin{tabular}{|l|l|l|l|}
\hline \multicolumn{3}{|c|}{ 27. Niue } \\
\hline Location & City & \multicolumn{1}{c|}{ Year \# } \\
\hline Polynesia & Sydney & 1863 & $\# 7022$ \\
\hline Polynesia & Sydney & 1866 & $\# 7023$ \\
\hline Polynesia & Sydney & 1870 & $\# 7025$ \\
\hline
\end{tabular}
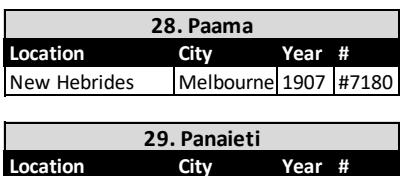

\begin{tabular}{|l|l|l|l|}
\hline British New Guine & Sydney & 1894 & $\# 7236$ \\
\hline
\end{tabular}

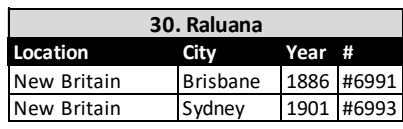

\begin{tabular}{|l|l|l|l|}
\hline \multicolumn{4}{|c|}{ 31. Rotuma } \\
\hline Location & \multicolumn{1}{c|}{ City } & Year \# \\
\hline Polynesia & Hobart & 1857 & $\# 7711$ \\
\hline Polynesia & Melbourne & 1867 & $\# 7712$ \\
\hline Polynesia & Sydney & 1870 & $\# 7713$ \\
\hline Polynesia & Sydney & 1905 & $\# 7715$ \\
\hline
\end{tabular}

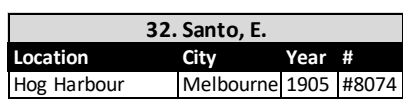

\begin{tabular}{|l|l|l|l|}
\hline \multicolumn{3}{|c|}{ 19. Malekula-Sinesip } \\
\hline \multicolumn{1}{|c|}{ City } & \multicolumn{1}{c|}{ Year \# } \\
\hline Location & Sydney & 1905 & $\# 6608$ \\
\hline New Hebrides & Melbourne & 1906 & $\# 6613$ \\
\hline New Hebrides & & &
\end{tabular}

\begin{tabular}{|l|l|l|l|}
\hline \multicolumn{4}{|l|}{ 20. Malekula-Uripiv } \\
\hline Location & \multicolumn{2}{l|}{ City } & \multicolumn{2}{l|}{ Year \# } \\
\hline New Hebrides & Melbourne & 1893 & $\# 6604$ \\
\hline New Hebrides & Melbourne & 1899 & $\# 6605$ \\
\hline New Hebrides & Melbourne & 1905 & $\# 6606$ \\
\hline
\end{tabular}

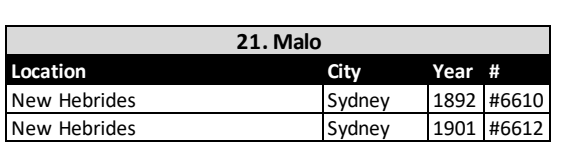
\begin{tabular}{|l|l|l|l|}
\hline New Hebrides & Sydney & 1901 & \#6612 \\
\hline
\end{tabular}

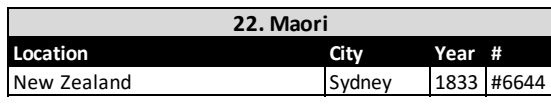
\begin{tabular}{|l|l|l|l|}
\hline New Zealand & Sydney & 1833 & $\# 6644$ \\
\hline
\end{tabular}

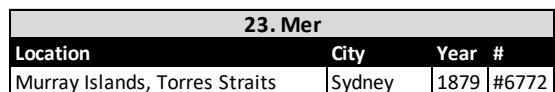
\begin{tabular}{|l|l|l|l|l|}
\hline Murray Islands, Torres Straits & Sydney & 1879 & $\# 6772$ \\
\hline Murray Island, Torres Straits & Sydney & 1885 & $\# 6774$ \\
\hline
\end{tabular} Murray Islands, Torres Straits $\quad$ Sydney 1885 \#6774 Port Moresby, British New Guinea Sydney 1882 \#6870 \begin{tabular}{|l|l|l|l|}
\hline Port Moresby, British New Guinea & Sydney & 1883 & $\# 6871$ \\
\hline Port
\end{tabular} \begin{tabular}{|l|l|l|l|}
\hline Port Moresby, British New Guinea & Sydney & 1885 & $\# 6872$ \\
\hline Port Moresb, Britsh Nw Gunea & Sydney & 1896 &
\end{tabular} \begin{tabular}{|l|l|l|l|}
\hline Port Moresby, British New Guinea & Sydney & 1896 & $\# 6875$ \\
\hline
\end{tabular}
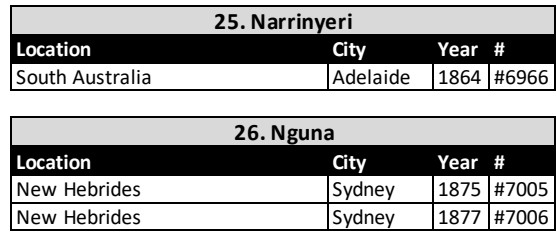

\begin{tabular}{|l|l|l|l|}
\hline Location & City & Year \# \\
\hline Nogugu, Nogugu & Melbourne & 1901 & \#8068 \\
\hline
\end{tabular}
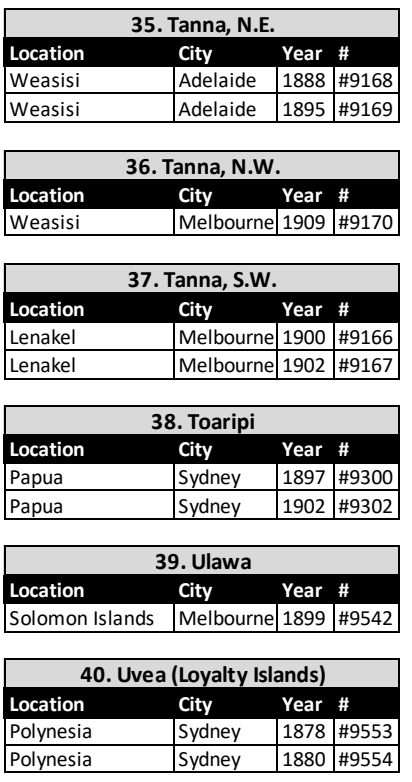

\begin{tabular}{|l|l|l|l|}
\hline \multicolumn{4}{|c|}{ 41. Wedau } \\
\hline Location & City & \multicolumn{2}{c|}{ Year \# } \\
\hline Papua & Sydney & 1895 & $\# 9568$ \\
\hline Papua & Sydney & 1897 & $\# 9569$ \\
\hline Papua & Sydney & 1902 & $\# 9572$ \\
\hline Papua & Sydney & 1903 & $\# 9574$ \\
\hline Papua & Sydney & 1907 & $\# 9575$ \\
\hline
\end{tabular}

\begin{tabular}{|l|l|l|l|}
\hline Solomon Islands & Melbourne & 1899 & \#9542 \\
\hline
\end{tabular}

Figure 1. The figure above is organized according to the languages listed for the Australian publishing cities of Adelaide, Brisbane, Hobart, Melbourne and Sydney, which lists the years ranging from 1833 [1827]-1909 in the Historical Catalogue of the Printed Editions of the Holy Scripture in the British and Foreign Bible Society (British and Foreign Bible Society 1903-1911). The languages, locations, years and catalogue numbers are listed in the form in which they appear and do not reflect contemporary geographical place names. 


\section{Religion after Print}

Australian religion became bound up with a printed context of publication practices. While often presented as interior and private, religion was persistently publicized in a way that contradicted that notion of interiority. While claiming religion was private, settlers devoted technical resources to materializing that notion in a rich context of publication practices. This context created opportunities for religious traditions willing and able to influence printed practices in Australia. These religious denominations were often minorities in the population, but they nonetheless became more visible through their technical capacity to print sacred texts.

In Australia, religious reading practices coalesced with broader literacy rates in the nineteenth-century. Estimates of Australian settler literacy at mid-nineteenth-century vary. ${ }^{24}$ However, as Martyn Lyons and Lucy Taksa note in their Australian Readers Remember, by the end of the nineteenth-century, it can be estimated that roughly " $95 \%$ of [settler] Australians could read and write" (Lyons and Taksa 1992, p. 7). Lyons and Taksa's account of Australian reading was based on a series of oral histories that sought to look back from the twentieth to nineteenth-century reading practices (Lyons and Taksa 1992, pp. 193-94). On the surface, it appears as a relatively small sample and example. However, his chapter on religious reading echoes much of the analysis of European Pietist readers, with family Bibles heavily featured and repetitious intimate reading practices of that same text in the foreground (Lyons and Taksa 1992, p. 31). Other similar brief references to religious reading can be found in Martin Lyons and John Arnold's A History of the Book in Australia: 1891-1945 (Lyons and Arnold 2001). There, they note how bush life impacted the reception of the Bible in such cases as fictional figures in Tom Collins novels (Lyons and Arnold 2001, p. 343), and in the diaries of early twentieth-century Queenslanders who read the Bible in distinctive ways (Lyons and Arnold 2001, pp. 348-49).

In large part, these religious reading practices of Australia's past had been eroded if not lost over the course of the twentieth-century (Lyons and Taksa 1992, p. 28). Nonetheless, religious print provides insights into the material aspects of Australian settler cultures of the eighteenth and nineteenth-centuries. Just as in Europe, texts such as the Bible became some of the most widely recognized aspects of religion in a public sphere reliant on printed communications. Recovering the visibility of religion in that context may reframe its relation to information technology more widely for contemporary cultures going through digital transformations. Moreover, this context of Australia's printed religious texts provides a number of avenues to reconsider the history of the country's multireligious diversity.

To that end, while beyond the scope of the present essay's interest in the printed aspects of Australia's early settler public sphere, it is hoped that the methodological approach exemplified here may inspire future research in the study of the material impact of religious texts more widely. Firstly, it is possible that early Muslim traders from Indonesia in the eighteenth and nineteenth-centuries in northern Australia brought manuscript Qur'an's with them. New research may yet also uncover the material form of religious texts imported by Muslims working on the Ghan railway line (Stephenson 2010, p. 70). These would most likely have been in manuscript form, especially for the early Broken Hill Mosque built in 1887 (Stephenson 2010, p. 107). ${ }^{25}$ However, given Islamic prohibitions of print were relaxed in the eighteenth-century it is possible that lithographic print Qur'ans are part of the material history of Islamic texts in Australia. ${ }^{26}$ Such examples could complement those printed by Christian authors, such as George Sale's English translation (Sale 1734). ${ }^{27}$

Secondly, while Hebrew Bibles and Talmuds were not printed in Australia before the twentieth-century, Jewish settlers would also have brought their sacred texts with them. As bibliographers have noted, Jewish sacred texts are notable for their persistently varied forms between manuscript, print, codex and scroll (Schrijver 2007, p. 160). The history of Jewish print is complex and included Christian censorship in Europe from the sixteenth-century onwards (Schrijver 2007, p. 157). However, a Jewish printing industry did develop early in Australia's history (Marks 1913). While primarily producing news 
and other texts, an early example of a religiously oriented text included an 1833 rulebook, "Laws and Rules for the Management of the Sydney Synagogue", which Ferguson records. As he noted, "From 1831 onwards a regularly constituted congregation- the first Australian Jewish Community ... The premises ceased to be so employed in 1844" (Ferguson 1948, p. 110).

Lastly, and maybe most promisingly in the Oceania context, the history of religious print may also foster the recognition of Indigenous languages that were translated in the settler era. The table above provides the potential to map the scope of such a project. It could be used to thus complement similar language recovery work taking place in other parts of the world. ${ }^{28}$

Funding: This research was funded by the State Library of New South Wales: Australian Religious History Fellowship.

Institutional Review Board Statement: Not applicable.

Informed Consent Statement: Not applicable.

Data Availability Statement: Not applicable.

Conflicts of Interest: The author declares no conflict of interest.

\section{Notes}

1 The essay inverted the title of an essay he had published ten years prior which explored similar options (Smith 2009, p. 5, citing; Smith [1999] 2004). Both essays acknowledge the prior work of Wilfred C. Smith who examined the possibility of a similar historical study of religious texts along these lines (Smith 1971).

2 Barker is a legal scholar who has suggested that Australian secularism is closest to Charles Taylor's third definition in A Secular Age (Taylor 2007, p. 203). That is, not a complete removal of God and religion from the public sphere, nor reduction of religious belief in the general population, but rather, where "religion ... is just once voice among many, including those with no religion" (Barker 2015).

3 This difficulty is reiterated in the opening remarks in Chavura, Gascoigne and Tregenza's Reason, Religion and the Australian Polity, where renewed scholarly debate about the visibility of "public religion" is discussed primarily in terms of the institutional relation between "'religion' and the modern state." (Chavura et al. 2019, p. 4). The approach taken here aims to complement existing research by providing a concrete example of how print provided material context to publicize religion in a public sphere. For a wider discussion of the ways the public private distinction can be applied to religion, see José Casanova's Public Religions in the Modern World, (Casanova 1994, pp. 41-42).

4 Habermas dates the English language notion of public opinion to 1781 in the Oxford English Dictionary (Habermas [1962] 1989, p. 95). He also acknowledges that the idea of the public varied in philosophical treatises by Thomas Hobbes, John Locke, Jean-Jacques Rousseau and Immanuel Kant (Habermas [1962] 1989, pp. 90-106). Nonetheless, his reliance on Kant's “What is Enlightenment?" (Kant [1784] 1996) is particularly telling: “Each person was called to be a 'publicist,' a scholar 'whose writings speak to his public, the world"" (Habermas [1962] 1989, p. 106).

5 The context was inevitably mixed in its use of texts over this period, and print was not a deterministic fate, so much as part of what Elizabeth Eisenstein calls, a "change of phase" in how these communication practices came to interact with each other (Eisenstein 2005, p. 332). It should also be noted that orality persisted alongside this diversity of printed materials. Many published sermons apologized for their lack of a preacher's presence (McKenzie 2002, p. 241). As Andrew Pettegree has noted, in his recent Brand Luther, the reformer cultivated a kind of publicity and fame both as a preacher and in his printed work (Pettegree 2015, Loc 69). Nonetheless, book historians such as Chartier demonstrate an overall increase in engagement with various forms of reading and writing practices over the seventeenth and eighteenth-centuries (Chartier 2003b, pp. 111-16).

6 Despite their differences, early Protestant and Counter-Reformation Catholics of the sixteenth and seventeenth-centuries both emphasized the importance of preaching as well as liturgical practices. Each developed new ways for private religious community to develop in this era. As Lebrun notes, "both the Protestant Reformation and the Catholic Counter-Reformation played key roles in the internalization of piety" (Lebrun 2003, p. 109).

7 The details of specific Pietist doctrines or thought are beyond this essay's focus upon the way their view of inner religious life relied on printed publications practices. They paradoxically publicized that view in a way that made religion more visible in the public sphere of printed communications. For a more full discussion of these relationships in the English context see (Green 2000).

8 For a summary of Wesley's Pietist thought, see (Hempton 2004, pp. 257-72).

9 While Australian history of the book is well underway (Munro and Sheahan-Bright 2006; Lyons and Arnold 2001; Kirsop 1969; Kirsop 1988), less emphasis has been placed on religious texts. Research on the relationship between European importation and 
Australian printing was commenced by Wallace Kirsop (Kirsop 1962, 1969, p. 19). As Kirsop noted, Australia's distance from Europe meant that it began producing its own printed materials much earlier than other colonial contexts such as Canada. As he put it at one point, 'Isolation, then, is the initial impulse towards creating a printing industry' (Kirsop 1969, p. 12).

None are included in John Ferguson's multivolume Bibliography of Australia (Ferguson 1941, 1948, 1951, 1955, Ferguson 1963-1969), nor are any listed in the first volume of the Historical Catalogue of the Printed Editions of the Holy Scripture in the British and Foreign Bible Society (British and Foreign Bible Society 1903-1911), which lists all English editions.

11 The details of these events have been summarized in more detail in Robb's biography George Howe: Australia's First Publisher (Robb 2003, pp. 14-19). For instance, it is worth noting that George had been sentenced to death for shoplifting. That sentence was commuted to transportation to Australia.

12 Blair also notes that George "served on committees and printed the records of groups such as the New South Wales Society for Promoting Christian Knowledge and Benevolence, the New South Wales Sunday School Institution the Auxiliary Bible Society of new South Wales and Wesleyan Auxiliary Missionary Society" (Blair 1985, pp. 16-17).

13 Carey estimates that by 1871 Methodists made up $9.7 \%$ of the population of New South Wales and by the turn of the twentiethcentury did not exceed 10\% of the population. Wright and Clancy conclude, "By 1902 there were twenty-seven circuits and 2036 members, though the church had peaked in 1894-1895 with twenty-nine ministers, 142 local preachers, 2187 members and 7296 Sunday school scholars" (Wright and Clancy 1993, p. 52).

To reiterate, the aim of this paper is to demonstrate key features of early Australian print culture that fit Habermas's outline of a public sphere. It is in this sense an ideal, with varying degrees expression in debate, readership and publication practices.

As D. F. McKenzie commented with regard to the New Zealand context, the vernacular literacy aims of the missionaries were driven by complex interests. "The missionaries were all too well aware that English would give the Maori access to the worst aspects of European experience. By containing them culturally within their own language, they hoped to keep them innocent of imported evils. By restricting them further to the reading of biblical texts and vocabulary, they limited the Maori to knowledge of an ancient middle-eastern culture; at the same time the missionaries enhanced their familiar pastoral role by making the Maori dependent on them morally and politically as interpretative guides to Pakeha realities" (McKenzie 1999, p. 84).

16 The issue of the Sydney Gazette cited, discusses missionary practices to Tahiti and notes the following, "By direction of the Rev. Mr. Marsden, several Scriptural translations have been printed here and are in readiness to be conveyed thither as soon as an opportunity shall offer" (Sydney Gazette and New South Wales Advertiser 1814). This citation is also included in Ferguson's notes.

17 The first printed Christian scriptures in North America were of a New Testament translation of the Indigenous Algonquin language dialect of the Wôpanâak people living in Massachusetts. It is known as the Wampanoag Bible and alternatively the Eliot Bible after its translator John Eliot (Wusku Wuttestamentum Nul-Lordumun Jesus Christ nuppoquohwussuaeneumun 1661). The complete Bible in the same language was published two years later in 1663. A discussion of the latter text can be found in Hamel's The Book: A History of the Bible (Hamel 2001, pp. 270-74). While Hamel briefly discusses translations into Fijian, Tahitian and Maori (Hamel 2001, pp. 291-94), but makes no mention of Australian printing practices nor Australia's Indigenous languages.

18 The Historical Catalogue of the Printed Editions of the Holy Scripture in the British and Foreign Bible Society lists an entry for the year 1833, with notes concerning its 1827 publication in Sydney (British and Foreign Bible Society 1903-1911, p. 1071).

19 One of the first printed Maori language texts was produced in 1815 as a spelling primer, entitled ed: “A Korao no New Zealand; /or, the/New Zealander's First Book; /being/An Attempt to compose some Lessons for the/Instruction of the Natives" (Parr 1961, 429; citing Williams 1924). As D. F. McKenzie noted, the first printing press arrived in New Zealand in 1830 (McKenzie 1999, p. 96).

20 This would be roughly 3405.80 pounds today, as calculated at: https:/ /www.officialdata.org/uk/inflation/1800?amount=41. (accessed on 2 February 2019).

21 At the University of Newcastle we acknowledge the Awabakal people as the traditional owners of the land upon which we work, and pay respect to the Elders past, present and future.

22 In both the Tahitian and Maori cases, Ferguson also records early hymns and catechism publications (Ferguson 1941, p. 241 [Tahitian Catechism], p. 241 [Tahitian Language Primer], p. 253, [Tahitian Hymns], p. 249 [Maori Language Primer], p. 416 [Maori Wesleyan Catechism], p. 495 [Maori Scripture Portions, Prayers, Catechism and Hymns]).

23 For another example listing printed Indigenous translations see Bernard Pick's (1913) American Bible Society pamphlet, Translations of the Bible: A Chronology of the Versions of the Holy Scriptures Since the Invention of Printing, which lists Tahitian in 1818 and Maori in 1833. Awabakal is listed in 1891.

24 A summary of the literacy rate in relation to religious and economic backgrounds around the time of the influx of immigration in 1841 can be found in (Richards 1999, p. 347).

25 The mosque is now a museum heritage site. 'Broken Hill Mosque Museum', Broken Hill City Council, at <https://www. brokenhill.nsw.gov.au/Community/About-the-city/Outback-Museum-Stories/Broken-Hill-Mosque-Museum>. Accessed on 6 January 2021. 
26 The earliest printed Qur'an in Arabic dates from “around 1537 in Venice," with the Pope's sanction of other Arabic translation projects (Atiyeh 1995, 2050-51n1). The earliest Islamic bans on print in the Ottoman context date from 1482 and were not lifted until 1727 (Albin 2007, p. 170). Lithography fostered more accurate preservation of manuscript aesthetics in Arabic. The first edition of the Qur'an was produced in Iran in 1832-33, when beloved nastaliq calligraphy script was able to be reproduced more beautifully. By 1848 in India's state of Oudh, lithography became known as a "Muslim technology" (Albin 2007, p. 174).

27 The earliest translation into English was in 1649 by Alexander Ross. The second English translation was by George Sale in 1734 (Robinson 1993, pp. 229-51). An early 1734 example of Sale's text exists in the State Library of New South Wales Richardson Collection.

28 As noted above, examples of Wôpanâak language sacred texts in the North American context are now held in the Huntington Library and feature in art gallery displays. They are also oft cited in the revival of that once extinct language. The Wôpanâak Language Reclamation Project cites a page from the 1663 Bible on the homepage of its website: https://www.wlrp.org. (Homepage 2021). It is hoped that the research and table produced here may inspire similar work in the Australian, New Zealand and Oceania contexts.

\section{References}

Adams, Thomas, and Nicolas Barker. 2001. A New Model for the Study of the Book. In A Potencie of Life: Books in Society. Edited by Nicholas Barker. London: British Library, pp. 5-44.

Albin, Michael. 2007. The Islamic Book. In A Companion to the History of the Book. Edited by Simon Eliot and Jonathan Rose. Malden: Blackwell, pp. 165-76.

Atiyeh, George N. 1995. The Book in the Modern Arab World: The Cases of Lebanon and Egypt. In The Book in the Islamic World: The Written Word and Communication in the Middle East. Edited by George N. Atiyeh. Albany: State University of New York Press, pp. 233-54.

Auxiliary Bible Society of New South Wales. 1822-1823. Sixth and Seventh Reports, Sydney.

Baker, Keith. 1996. Defining the Public Sphere in Eighteenth-Century France: Variations on a Theme by Habermas. In Habermas and the Public Sphere. Edited by Craig Calhoun. Cambridge: MIT Press, pp. 181-211.

Barker, Renae. 2015. Is Australia a Secular Country? It Depends What You Mean. The Conversation. May 14. Available online: http:/ / theconversation.com/is-australia-a-secular-country-it-depends-what-you-mean-38222 (accessed on 2 February 2019).

Blair, Sandy. 1985. George Howe and Early Printing in New South Wales. In Wayzgoose One. Pyrmont: Wayzgoose Press, pp. 2-22.

Borchardt, Dietrich Hans. 1988. Printing Comes to Australia. In The Book in Australia: Essays towards a Cultural and Social History. Edited by D. H. Borchardt and Wallace Kirsop. Melbourne: Australian Reference Publications in Association with the Centre for Bibliographical and Textual Studies, pp. 1-15.

British and Foreign Bible Society. 1903-1911. Historical Catalogue of the Printed Editions of the Holy Scripture in the British and Foreign Bible Society. London: The Bible House, vols. 1-4.

Canton, William. 1904. A History of the British and Foreign Society. London: John Murray, vol. 2.

Carey, Hilary M. 2010. Lancelot Threlkeld, Biraban, and the Colonial Bible in Australia. Comparative Studies in Society and History 52: 447-78. [CrossRef]

Carey, Hilary M. 2011. God's Empire: Religion and Colonialism in the British World, C.1801-1908. Cambridge: Cambridge University Press.

Casanova, José. 1994. Public Religions in the Modern World. Chicago: Chicago University Press.

Cavanaugh, William. 2009. The Myth of Religious Violence. Oxford: Oxford University Press.

Chartier, Roger. 2003a. Figures of Modernity: Introduction. In A History of Private Life: Passions of the Renaissance. Edited by Roger Chartier. Cambridge: Belknap Press of Harvard University Press, vol. 3, pp. 15-19.

Chartier, Roger. 2003b. The Practical Impact of Writing. In A History of Private Life: Passions of the Renaissance. Edited by Roger Chartier. Cambridge: Belknap Press of Harvard University Press, vol. 3, pp. 111-59.

Chavura, Stephen A., and Ian Tregenza. 2015. A Political History of the Secular in Australia: 1788-1945. In Religion after Secularization in Australia. Edited by Timothy Stanley. New York: Palgrave, pp. 3-32.

Chavura, Stephen A., John Gascoigne, and Ian Tregenza. 2019. Reason, Religion and the Australian Polity. New York: Routledge.

Darnton, Robert. 1990. What is the History of Books? In The Kiss of Lamourette: Reflections in Cultural History by Robert Darnton. New York: Norton, pp. 107-35.

Darnton, Robert. 1999. The Great Cat Massacre and Other Episodes in French Cultural History. New York: Basic Books.

Eisenstein, Elizabeth L. 2005. The Printing Revolution in Early Modern Europe. Cambridge: Cambridge University Press.

Eliot, Simon, and Jonathan Rose, eds. 2007. A Companion to the History of the Book. Malden: Blackwell Press.

Ferguson, John Alexander. 1941. Bibliography of Australia. Vol. 1: 1784-1830. Sydney: Angus and Robertson.

Ferguson, John Alexander. 1948. Bibliography of Australia. Vol. 2: 1831-1838. Sydney: Angus and Robertson.

Ferguson, John Alexander. 1951. Bibliography of Australia. Vol. 3: 1839-1845. Sydney: Angus and Robertson.

Ferguson, John Alexander. 1955. Bibliography of Australia. Vol. 4: 1846-1850. Sydney: Angus and Robertson.

Ferguson, John Alexander. 1963-1969. Bibliography of Australia. Vols. 5-7: 1851-1900. Sydney: Angus and Robertson.

Finkelstein, David, and Alistair McCleery. 2005. An Introduction to Book History. New York: Routledge.

Gascoigne, John. 2002. The Enlightenment and the Origins of European Australia. Cambridge: Cambridge University Press.

Green, Ian. 2000. Print and Protestantism in Early Modern England. New York: Oxford University Press. 
Habermas, Jürgen. 1989. The Structural Transformation of the Public Sphere: An Inquiry into a Category of Bourgeois Society. London: Polity Press. First published 1962.

Hamel, Christopher de. 2001. The Book: A History of the Bible. London: Phaidon Press.

Hempton, David. 2004. John Wesley (1703-1791). In The Pietist Theologians: An Introduction to Theology in the Seventeenth and Eighteenth Centuries. Edited by Carter Lindberg. Malden: Blackwell Publishing, pp. 256-72.

Homepage. 2021. Wôpanâak Language Reclamation Project. Available online: https:/ / www.wlrp.org (accessed on 6 January 2021).

Howe, George. 1821a. Advertisement. In An Abridgment of the Wesleyan Hymns Selected from the Larger Hymn-Book, Published in England, for the Use of the People Called Methodist. Sydney: Printed by George Howe.

Howe, Robert. 1821b. Preface [to the December Index of the Complete First Volume]. In The Australian Magazine: Or, Compendium of Religious, Literary, and Miscellaneous Intelligence. Sydney: Printed by Robert Howe, vol. 1.

Howsam, Leslie. 2014. The Cambridge Companion to the History of the Book. Cambridge: Cambridge University Press.

Johnston, Anna. 2001. The Book Eaters: Textuality, Modernity and the London Missionary Society. Semeia 88: 13-40.

Johnston, Anna. 2003. Missionary Writing and Empire, 1800-1860. Cambridge: Cambridge University Press.

Johnston, Anna. 2006. A Blister on the Imperial Antipodes: Lancelot Edward Threlkeld in Polynesia and Australia. In Imperial Careering in the Long Nineteenth Century. Edited by David Lambert and Alan Lester. Cambridge: Cambridge University Press, pp. 58-87.

Kant, Immanuel. 1996. An Answer to the Question: What is Enlightenment? In Practical Philosophy. Edited by Mary J. Gregor. Cambridge: Cambridge University Press, pp. 58-87. First published 1784.

Kenehihi: Ko te tahi o nga upoko. 1827. Sydney: G. Eager Printer (Seen through the press by Richard Davis).

Kirsop, Wallace. 1962. Sources in Australian Libraries for the Religious History of the XVIth and XVIIth Centuries: A Preliminary Survey. Journal of Religious History 2: 168-77. [CrossRef]

Kirsop, Wallace. 1969. Towards a History of the Australian Book Trade. Sydney: Wentworth Books.

Kirsop, Wallace. 1988. Bookselling and Publishing in the Nineteenth Century. In The Book in Australia: Essays towards a Cultural and Social History. Edited by Dietrich Hans Borchardt and Wallace Kirsop. Melbourne: Australian Reference Publications in Association with the Centre for Bibliographical and Textual Studies, pp. 16-42.

Lake, Meredith. 2018. The Bible in Australia: A Cultural History. Sydney: Newsouth.

Lebrun, François. 2003. The Two Reformations: Communal Devotion and Personal Piety. In A History of Private Life: Passions of the Renaissance. Edited by Roger Chartier. Cambridge: Belknap Press of Harvard University Press, vol. 3, pp. 69-110.

Lyons, Martyn, and John Arnold. 2001. A History of the Book in Australia, 1891-1945: A National Culture in a Colonised Market. St Lucia: University of Queensland Press.

Lyons, Martyn, and Rita Marquilhas. 2017. New Directions in Book History: Approaches to the History of Written Culture. New York: Palgrave Macmillan.

Lyons, Martyn, and Lucy Taksa. 1992. Australian Readers Remember: An Oral History of Reading 1890-1930. Melbourne: Oxford University Press.

Macintosh, Richard. 1978. Richard Johnson. Chaplain to the Colony of New South Wales. His Life and Times 1755-1827. Sydney: Library of Australian History.

Marks, Percy Joseph. 1913. The Jewish Press of Australia Past and Present: A Paper Read before the Jewish Literary and Debating Society of Sydney. Sydney: F. W. White.

McKenzie, Donald Francis. 1999. Bibliography and the Sociology of Texts. Cambridge: Cambridge University Press.

McKenzie, Donald Francis. 2002. Speech-Manuscript-Print. In Making Meaning: "Printers of the Mind" and Other Essays. Edited by Peter McDonald and Michal Suarez. Amherst: University of Massachusetts Press, pp. 237-58.

Monsma, Stephen V., and J. Christopher Soper. 2009. The Challenge of Pluralism: Church and State in Five Democracies. Lanham: Rowman \& Littlefield Publishers.

Munro, Craig, and Robyn Sheahan-Bright. 2006. Paper Empires: A History of the Book in Australia, 1946-2005. St. Lucia: University of Queensland Press.

Parau no Iesu Christ te Temaidi no te Atua: E no te mou pipi nona. 1814. Sydney: Printed by George Howe.

Parr, Christopher J. 1961. A Missionary Library: Printed Attempts to Instruct the Maori, 1815-1845. The Journal of the Polynesian Society 70: $429-50$.

Pettegree, Andrew. 2015. Brand Luther: 1517, Printing, and the Making of the Reformation. New York: Penguin.

Pick, Bernard. 1913. Translations of the Bible: A Chronology of the Versions of the Holy Scriptures Since the Invention of Printing. New York: American Bible Society.

Prentis, Malcolm. 2015. Methodism in New South Wales, 1855-1902. In Methodism in Australia: A History. Edited by Glen O'Brien and Hilary M. Carey. New York: Routledge, pp. 29-44.

Richards, Eric. 1999. An Australian Map of British and Irish Literacy in 1841. Population Studies 53: 345-59. [CrossRef]

Robb, Gwenda. 2003. George Howe: Australia's First Publisher. Melbourne: Australian Scholarly Publishing.

Robinson, Francis. 1993. Technology and Religious Change: Islam and the Impact of Print. Modern Asian Studies 27: 229-51. [CrossRef]

Sale, George. 1734. The Koran, Commonly Called the Alcoran of Mohammed/Translated into English Immediately from the Original Arabic; With Explanatory Notes, Taken from the Most Approved Commentators: To which Is Prefixed a Preliminary Discourse. London: Printed by C. Ackers for J. Wilcox. 
Schrijver, Emile G. L. 2007. The Hebraic Book. In A Companion to the History of the Book. Edited by Simon Eliot and Jonathan Rose. Malden: Blackwell, pp. 153-64.

Shantz, Douglas. 2013. An Introduction to German Pietism: Protestant Renewal at the Dawn of Modern Europe. Baltimore: The Johns Hopkins University Press.

Smith, Jonathan Z. 2013. Scripture and Histories. In On Teaching Religion: Essays by Jonathan Z. Smith. New York: Oxford University Press, pp. 28-36. First published 1992.

Smith, Jonathan Z. 2004. Bible and Religion. In Relating Religion: Essays in the Study of Religion. Chicago: University of Chicago Press, pp. 197-214. First published 1999.

Smith, Wilfred C. 1971. The Study of Religion and the Study of the Bible. Journal of the American Academy of Religion 39: 131-40. [CrossRef]

Smith, Jonathan Z. 1978. Map Is Not Territory: Studies in the History of Religions. Leiden: Brill.

Smith, Jonathan Z. 2009. Religion and Bible. Journal of Bibilical Literature 128: 5-27. [CrossRef]

Stephenson, Peta. 2010. Islam Dreaming: Indigenous Muslims in Australia. Sydney: University of New South Wales Press.

Sydney Gazette and New South Wales Advertiser. 1814. Volume 12.574. December 3.

Tate, Nahum, and Nicholas Brady. 1828. Select Portions of Brady and Tate's Version of the Psalms. Hymns for Special Occasions. Doxologies. [Select Portions of the Psalms of David according to the Version of Dr. Brady and Mr. Tate, to Which Are Added Hymns for the Celebration of Church Holy-Days, and Festivals]. Sydney: Printed by Robert Howe.

Taylor, Charles. 2007. A Secular Age. Cambridge: Belknap press of Harvard University Press.

Threlkeld, Lancelot. 1892. An Australian Grammar Comprehending the Principles and Natural Rules of the Language as Spoken by the Aborigines in the Vicinity of Hunter's River, Lake Macquarie, New South Wales. Sydney: Stephens and Stokes, Herald Office. First published 1834 .

Threlkeld, Lancelot. 1827. Specimens of a Dialect of the Aborigines of New South Wales, 1826, Sydney.

Threlkeld, Lancelot. 1897. Euangelion Unni Ta Jesu-Umba Christ-Ko-Ba Upatoara Luke-Umba. The Gospel of Jesus Christ According to Luke in Awabakal and English (R.S.V.). Ingleburn: N.S.W Bible Society in Australia.

Vliet, Rietje van. 2007. Print and Public in Europe 1600-1800. In A Companion to the History of the Book. Edited by Simon Eliot and Jonathan Rose. Malden: Blackwell Press, pp. 247-58.

Warner, Michael. 1992. Letters of the Republic: Publication and the Public Sphere in Eighteenth-Century America. Cambridge: Harvard University Press.

Wesley, John. 1821. An Abridgment of the Wesleyan Hymns Selected from the Larger Hymn-Book, Published in England, for the Use of the People Called Methodists. Sydney: Printed by George Howe.

Williams, Herbert William. 1924. A Bibliography of Printed Maori to 1900. Wellington: Dominion Museum Monograph.

Wright, Don, and Eric Clancy. 1993. The Methodists: A History of Methodism in New South Wales. St. Leonards: Allen and Unwin.

Wusku Wuttestamentum Nul-Lordumun Jesus Christ nuppoquohwussuaeneumun. 1661. Cambridge: Printed by Samuel Green and Marmaduke Johnson.

Zaret, David. 1996. Religion, Science, and Printing in the Public Spheres in Seventeenth-Century England'. In Habermas and the Public Sphere. Edited by Craig Calhoun. Cambridge: MIT Press, pp. 212-35. 